\title{
A Study of Cardiac Autonomic Functions in Patients with Chronic Stable Angina Undergoing Percutaneous Coronary Revascularization
}

\author{
Perkütan Koroner Revaskülarizasyon Geçiren Kronik Stabil Anjinli \\ Hastalarda Kardiyak Otonomik Fonksiyonlar Üzerine Bir Çalışma
}

\author{
Waqas ALAUDDIN $\odot$, Meenakshi CHASWAL $\odot$, Musharaf BASHIR $\odot$, Harmohander Singh ISSER $\odot$
}

\begin{abstract}
Ethics Committee Approval: This study was approved by Vardhman Mahavir Medical College and Safdarjung Hospital Ethics Committee, 30 October 2017, 2017-177

Conflict of interest: The authors declare that they have no conflict of interest.

Funding: None.

Informed Consent: Informed consents were taken from the participants of the study.

ABSTRACT

Objective: In the present study, cardiac autonomic functions in CSA patients were evaluated before and after percutaneous coronary intervention (PCI) using heart rate variability (HRV).

Methods: Thirty patients with CSA were recruited from cardiology outpatient clinics of VMMC and Safdarjung hospital, New Delhi, India. For each patient HRV parameters (LF, HF, LF:HF ratio, SDNN, RMSSD, total power, and PNN50) were gathered before and after PCI. Data were compiled and analyzed using licensed statistical software: SPSS version 21.0.

Results: Out of 30 subjects, SDNN $(61.47 \pm 22.27$ vs. $32.24 \pm 16.50 \mathrm{~ms}, \quad p<0.0001), \quad R M S S D$ (53.86 \pm 31.41 vs. $28.81 \pm 23.80 \mathrm{~ms}, p=0.001)$ and $p N N 50(46.24 \pm 34.36$ vs. $5.20 \pm 6.63, p<0.0001)$ in post-PCI were significantly higher as compared to the pre- $\mathrm{PCl}$ values. There were significant increases in both LF $\left(1193 \mathrm{~ms}^{2} \pm 302.04 m s^{2} v s\right.$. $\left.1054.60 \mathrm{~ms}^{2} \pm 208 \mathrm{~ms}^{2}, p<0.001\right)$ and HF $\left(991.57 \pm 872.40 \mathrm{~ms}^{2} v \mathrm{~s}\right.$. $\left.466.72 m s^{2} \pm 257.93 m s^{2}, p<0.0001\right)$, also in total power $\left(3548.37 \mathrm{~ms}^{2} \pm 807.73 \mathrm{~ms}^{2} \mathrm{vs}\right.$. $2428 \mathrm{~ms}^{2} \pm 867.07$ $\mathrm{ms}^{2}, p<0.0001$ ) in post-PCl as compared to pre-PCI. The LF:HF ratio in pre-PCl was higher as compared to post-PCI $(1.467 \pm 1.639$ vs. $1.143 \pm 0.852, p=0.805)$, but the difference was not statistically significant. Conclusion: In this preliminary study, it is concluded that there is significant improvement in resting cardiovascular parameters, resting autonomic tone as measured by HRV which shows increase in both parasympathetic as well as sympathetic reactivity following revascularization by $\mathrm{PCI}$ in CSA patients. Hence, we also suggest that the use of noninvasive tests such as HRV should be done to stratify further risk of disease progression.
\end{abstract}

Cite as: Alauddin W, Chaswal M, Bashir M, Isser HS. A study of cardiac autonomic functions in patients with chronic stable angina undergoing percutaneous coronary revascularization. Medeni Med J. 2021;36:91-7.
Keywords: Sudden cardiac death, heart rate variability, percutaneous coronary intervention, chronic stable angina, autonomic dysfunction

öz

Amaç: Bu çalıșmada kronik stabil anjina (KSA) hastalarında kardiyak otonom fonksiyonlar, perkütan koroner girişim (PKG) öncesi ve sonrası kalp hızı değişkenliği (KHD) kullanılarak değerlendirilmiştir. Yöntem: Otuz KSA hastası, Hindistan'da Yeni Delhi'deki VMMC ve Safdarjung hastanesinin kardiyoloji bölümü ayaktan hasta kliniğinden alınmıștır. Her hasta için PKG'den önce ve sonra KHD parametreleri (LF, HF, LF:HF oranı, SDNN, RMSSD, Toplam güç ve pNN50) alınmıştır. Veriler, lisanslı istatistiksel yazılım SPSS sürüm 21.0 kullanılarak derlenerek analiz edilmiştir.

Bulgular: Otuz hastadan SDNN $(61.47+22.27$ vs. $32.24+16.50 \mathrm{~ms}, p<0.0001), R M S S D(53.86+31.41$ vs. $28.81 \pm 23.80 \mathrm{~ms}, p=0.001)$ ve $p N N 50(46.24 \pm 34.36$ vs. $5.20 \pm 6.63, p<0.0001)$ PKG sonrasI, PKG öncesine klyasla anlamlı ölçüde daha yüksek çımıștır. Hem LF $\left(1193 \mathrm{~ms}^{2} \pm 302.04 \mathrm{~ms}^{2} v \mathrm{v}\right.$. $\left.1054.60 m s^{2} \pm 208 m s^{2}, p<0.001\right)$, hem HF $\left(991.57 \pm 872.40 m s^{2} v s .466 .72 m s^{2} \pm 257.93 m s^{2}, p<0.0001\right)$ hem de toplam güçte (3548.37 ms $\left.\pm 807.73 \mathrm{~ms}^{2} v s .2428 \mathrm{~ms}^{2} \pm 867.07 \mathrm{~ms}^{2}, p<0.0001\right)$ PKG öncesi PKG sonrası ile karşıllaştırıldığında anlamlı artış çımışstır. PKG öncesi LF:HF oranı, PKG sonrasına göre daha yüksek bulunmuştur (1.467 \pm 1.639 vs. $1.143 \pm 0.852, p=0.805)$, ancakistatistiksel olarak anlamlı bir fark bulunmamıştır

Sonuc: Bu ön çalıșmada, istirahat halindeki kardiyovasküler parametrelerde anlamlı iyileșme olduğu, KHD ile ölçülen istirahatteki otonom tonusun, KSA hastalarında PKG ile revaskülarizasyonu takiben hem parasempatik hem de sempatik reaktivitede artış gösterdiği sonucuna ulaşılmıştır. Bu nedenle, KHD gibi girişimsel olmayan testlerin, hastalı̆̆ın ilerleme riskinin daha katmanlı şekilde değerlendirilmesi için yapılmasını önermekteyiz.

Anahtar kelimeler: Ani kardiyak ölüm, kalp hızı değişkenliği, perkütan koroner girişim, kronik stabil anjin, otonom disfonksiyon

(c) Copyright Istanbul Medeniyet University Faculty of Medicine. This journal is published by Logos Medical Publishing. Licenced by Creative Commons Attribution-NonCommercial 4.0 International (CC BY-NC 4.0)
Received: 25 March 2021

Accepted: 14 May 2021

Online First: 18 June 2021

Corresponding Author:

W. Alauddin

ORCID: 0000-0001-5270-8164

Hinduhridaysamrat Balasaheb

Thackarey Medical College,

Dr. Rustom Narsi Cooper Hospital,

Juhu, Mumbai, India

dr.waqas7@gmail.com

M. Chaswal

ORCID: 0000-0001-7505-3260

Atal Biharl Vajpayee Institute of Medical Sciences,

Dr. Ram Manohar Lohia Hospital, New Delhi, India

M. Bashir

ORCID: 0000-0001-7836-3715 Government Medical College, Srinagar, Jammu and Kashmir, India

H.S. Isser

ORCID: 0000-0001-7915-5977 Vardhaman Mahavir Medical College, Safdarjung Hospital, New Delhi, India 


\section{INTRODUCTION}

Coronary artery disease is a key health concern today and has assumed epidemic proportions worldwide. Recent studies have showed that the prevalence of chronic coronary syndrome (CCS) has been increasing in the Indian population as well. In India, the prevalence of CCS has risen from $1.1 \%$ to $7.5 \%$ in the urban population and from $2.1 \%$ to $3.7 \%$ in the rural areas in the last three decades ${ }^{1}$. Chronic coronary syndrome is the main form of coronary artery disease and is of a stable type ${ }^{2}$. In the presence of chronic stable angina (CSA), the probabilities of adverse cardiovascular events such as myocardial infarction and cardiac death increase markedly ${ }^{3}$. CSA presents routinely as uneasiness, discomfort, or a squeezing pain in the chest, which is triggered or aggravated by exertion and is reduced by rest or by drugs such as nitroglycerin ${ }^{4}$. Anginal pain typical of CSA develops as a result of myocardial ischemia, which results in an imbalance between the demand and supply of oxygen to the myocardium. CSA causes severe atherosclerotic narrowing of one or more coronary vessels which is the underlying cause of the ischemic changes ${ }^{5}$. In these patients, imbalance in the autonomic regulation may occur because of chronic ischemia and hypoxia ${ }^{6,7}$. Some studies in the past observed a decrease in heart rate variability (HRV) indices in these patients, whereas others have reported that patients with CSA often have augmented sympathetic influence ${ }^{8,9}$. The chronic state of ischemic myocardium appears to be the reason for this autonomic dysfunction. In myocardial ischemia, the cause of autonomic dysfunction is postulated to be oxygen-deprived myocardium. Therefore, alleviation of this permanent state of autonomic dysregulation is the foremost goal of current treatment strategies for patients with CSA. Literature suggests that myocardial ischemia leads to autonomic dysregulation and that restoring vascularization improves the autonomic functions. Thus, enhancing the myocardial perfusion by percutaneous coronary intervention (PCI) might have beneficial effects on the recovery of autonomic balance in ischemiatriggered autonomic dysregulation.

To the best of our knowledge, few studies have investigated the autonomic function modulation of the cardiovascular system in patients with CSA and the effect of revascularization by PCI therapy on autonomic functions. The present study aimed to see whether there was an improvement in autonomic functions in patients with CSA who had undergone $\mathrm{PCI}$.

\section{MATERIAL and METHOD}

This is a pre-post study. This research was performed after obtaining ethical clearance from the Institutional Ethical Committee of VMMC and Safdarjung Hospital. The study was conducted from November 2017 to April 2019 in the Department of Physiology in collaboration with the Department of Cardiology, VMMC and Safdarjung Hospital, New Delhi. This investigation included 30 subjects of either sex who had CSA and were in the age group of 45-70 years. They were selected from the patients who visited the cardiology outpatient department of VMMC and Safdarjung Hospital. These subjects were scheduled for elective $\mathrm{PCl}$ of left anterior descending, right coronary artery and left main coronary artery. Subjects with a history of autoimmune disorders, collagen disease, uncontrolled hypertension, diabetes mellitus, left ventricular dysfunction with an ejection fraction $<35 \%$, heart failure, congenital heart disease, arrythmias, valvular heart disease, neuropsychiatric disorders, and other medical comorbidities were excluded from the study.

\section{Study design}

Heart rate variability analysis: All subjects were invited to the autonomic function testing laboratory in the Department of Physiology, VMMC and Safdarjung hospital, New Delhi, India. The protocol of HRV analysis was explained to them beforehand. On the day of testing, the subjects were instructed 
to lie down in the supine position. The electrodes for recording the electrocardiogram (ECG) in lead II were placed and the subjects were allowed to rest for 10-15 minutes, then the ECG was recorded for five minutes. Subjects were instructed to close their eyes throughout the procedure and to avoid activities such as talking, movement of the body, coughing and sleeping. Both time and frequency domain parameters were determined.

Time domain analysis: The parameters recorded by time-domain analysis were mean heart rate, standard deviation of all R-R intervals (SDNN), square root of mean squared differences of successive NN intervals (RMSSD), number of intervals differing by $>50 \mathrm{~ms}$ from the adjacent interval (NN50) and percentage of NN50 (pNN50).

Frequency domain analysis: This analysis was performed using a nonparametric method of fast Fourier transform (FFT). The power spectrum was subsequently quantified into standard frequencydomain measurements as defined previously, ${ }^{10}$ including total power (TP), low frequency (LF) (0.04-0.15 Hz), high frequency (HF) $(0.15-0.40$ $\mathrm{Hz}$ ) and LF:HF ratio. The $0.15-0.4 \mathrm{~Hz}$ band of $R-R$ power, which is considered as $H F$, reflects parasympathetic nerve activity on the heart, whereas $0.04-0.15 \mathrm{~Hz}$, which is considered as LF, represents sympathetic activity. The ratio of LF:HF represents sympathovagal balance ${ }^{11}$.

\section{Statistical analysis}

The data were compiled and entered in MS Excel and analysed using the licensed statistical software: SPSS version 21.0. The values were expressed as mean \pm standard deviation (SD). Statistical significance of the differences between pre-post interventions were carried out using paired Student's t-test or nonparametric tests. Multivariate analyses were done using regression analysis and Pearson's correlation coefficient. The significance level was considered as $\mathrm{p}<0.05$.

\section{RESULTS}

The present study included $30 \mathrm{PCl}$ candidates with CSA aged 45-70 years. Table 1 shows the basic characteristics of all subjects. The age of the CSA patients was $53.7 \pm 8.9$ years. Regarding gender distribution, study population consisted of 22 men (73.3\%) and 8 women (26.67\%), as shown in Figure 1. The mean age of the women was $51.25 \pm 10.81$ and that of the men was $54.29 \pm 8.376$ years. Body mass index of the subjects was found to be $24.23 \pm 2.59 \mathrm{~kg} / \mathrm{m}^{2}$.

Table 1. Basal characteristics of chronic stable angina patients.

\begin{tabular}{ll}
\hline Parameters & \multicolumn{1}{c}{$(\mathbf{n = 3 0 )}$} \\
\hline Age (yrs) & $53.7 \pm 8.9$ \\
Male & $22(73.3 \%)$ \\
Female & $8(26.67 \%)$ \\
BMI kg/m² & $24.23 \pm 2.59$ \\
History of diabetes & $3(10 \%)$ \\
History of hypertension & $5(16.66 \%)$ \\
History of hypertension \& diabetes & $14(46.66 \%)$ \\
Smokers & $17(56.66 \%)$ \\
Smokers+alcoholics & $4(13.33 \%)$ \\
Duration of CSA (months) & $7.56 \pm 5.05$
\end{tabular}

Values are expressed as mean \pm SD or number (\%). BMI-body mass index; n-number; CSA-Chronic stable angina.

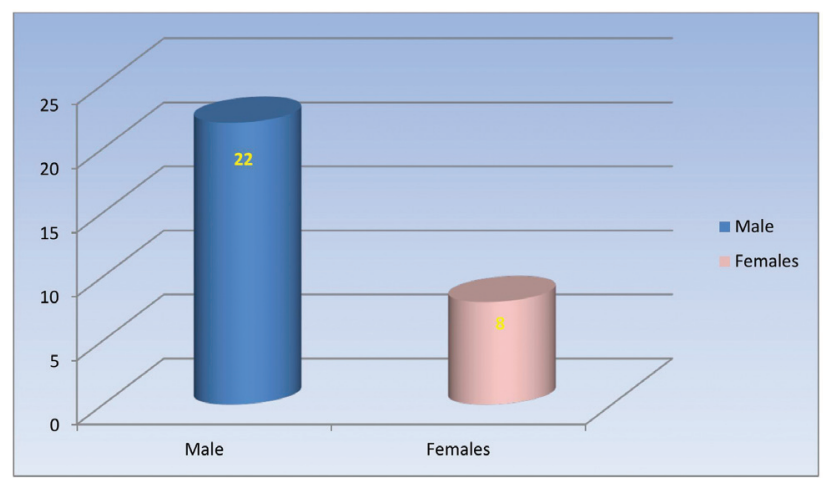

Figure 1. Comparison of gender distribution in chronic stable angina patients.

Males were more as compared to females.

Regarding the presence of comorbidities in the CSA patients, three (10\%) cases were diabetic, five (16.66\%) hypertensive and 14 (46.66\%) both diabeticandhypertensive. Furthermore, 17(56.66\%) patients had a history of smoking and four (13.33\%) 
had a history of both smoking and alcoholism, (Figure 2). The mean duration of stable angina was $7.56 \pm 5.05$ months. The time-domain parameters of SDNN $(61.47 \pm 22.27$ vs.32.24 $\pm 16.50 \mathrm{~ms}$, $\mathrm{p}<0.0001), \quad$ RMSSD $\quad(53.86 \pm 31.41 \mathrm{msvs}$. $28.81 \pm 23.80 \mathrm{~ms}, \quad \mathrm{p}=0.001)$ and $\mathrm{pNN50}$ $(46.24 \pm 34.36 v s$. $5.20 \pm 6.63, p<0.0001)$ in postPCI were significantly higher when compared with the pre-PCI values (Figure 4 and Table 2). There were significant increases in both post-PCI LF $\quad\left(1054.60 \mathrm{~ms}^{2} \pm 208 \mathrm{~ms}^{2} \mathrm{vs} . \quad 1193 \pm 302.04 \mathrm{~ms}^{2}\right.$,

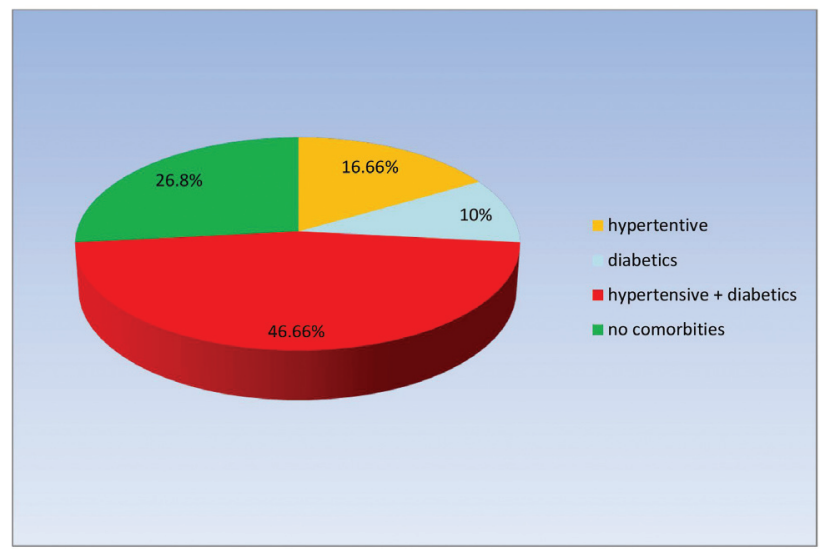

Figure 2. Distributions of co morbidities in patients of chronic stable angina.

46.66\% patients were having both Hypertension and Diabetes, $16 \%$ patients were hypertensives $10 \%$ patients were Diabetics and $26.8 \%$ patients had no comorbidities.

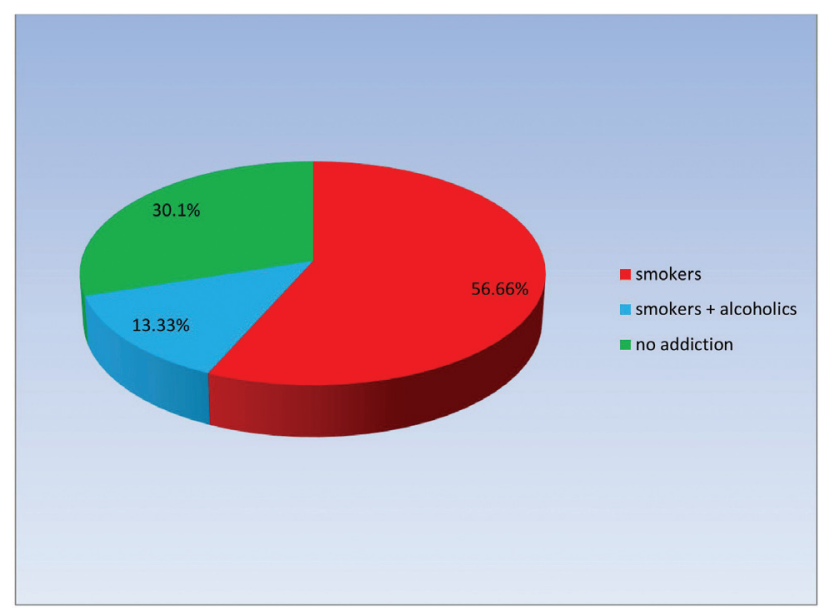

Figure 3. Distributions of history of addiction in patients of chronic stable angina.

13.33\% patients were both smokers and alcoholics, $56.66 \%$ patients were smokers and patients had no addiction. $\mathrm{p}<0.001)$ and HF $\left(991.57 \mathrm{~ms}^{2} \pm 872.40 \mathrm{~ms}^{2} \mathrm{vs}\right.$. $\left.466.72 \mathrm{~ms}^{2} \pm 257.93 \mathrm{~ms}^{2}, \quad \mathrm{p}<0.0001\right) \quad$ when compared with the pre-PCI values (Table 3 and Figure 5). Post-PCI TP was significantly increased as compared to pre-PCI $\left(3548.37 \pm 2428.58 \mathrm{~ms}^{2} \mathrm{vs}\right.$. $\left.807.73 \pm 867.07 \mathrm{~ms}^{2}, \mathrm{p}<0.0001\right)$. The LF:HF ratio in pre-PCI was higher as compared to post- $\mathrm{PCI}$ (1.467 \pm 1.639 vs. $1.143 \pm 0.852, \quad p=0.805)$, but the intergroup difference was not statistically significant (Table 3 and Figure 6).

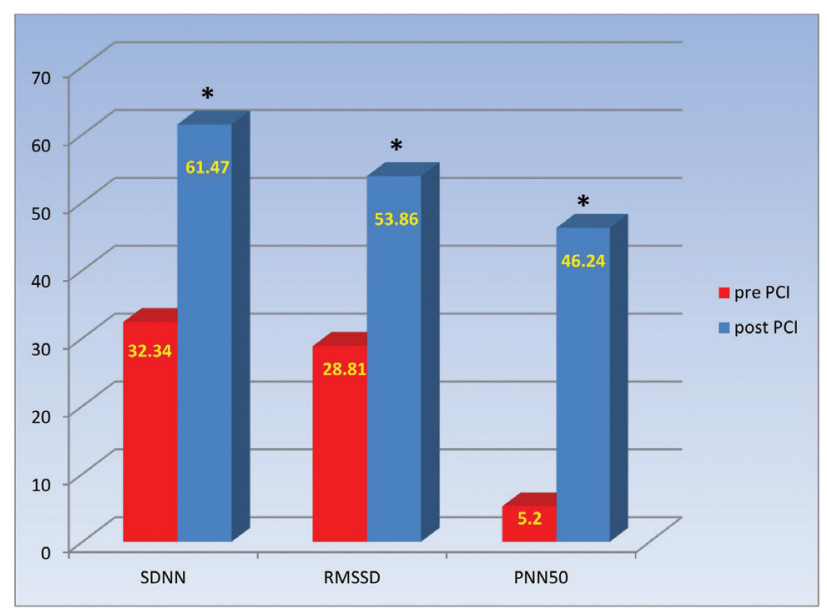

Figure 4. Comparison of Time domain parameters in chronic stable angina patients pre and post Percutaneous Coronary Intervention (PCI).

SDNN-standard deviation of the normal-to-normal R-to- $R$ interval; RMSSD-square root of mean squared differences of successive NN intervals; Post PCI showed significant improvement in SDNN, RMSSD and PNN5O as compared to Pre PCI.

${ }^{*} p$ value $<0.05$, statistically significant.

Table 2. Comparison of time domain parameters of heart rate variability in chronic stable angina patients pre and post Percutaneous Coronary Intervention (PCI).

\begin{tabular}{lllc}
\hline Parameters & $\begin{array}{l}\text { Pre-PCI } \\
(\mathbf{n = 3 0 )} \\
\text { Mean } \pm \text { SD }\end{array}$ & $\begin{array}{l}\text { Post-PCI } \\
(\mathbf{n = 3 0 )} \\
\text { Mean } \pm \text { SD }\end{array}$ & p Value \\
\hline SDNN (ms) & $32.24 \pm 16.50$ & $61.47 \pm 22.27$ & $<0.0001$ \\
RMSSD (ms) & $28.81 \pm 23.80$ & $53.86 \pm 31.41$ & 0.001 \\
pNN50 (\%) & $5.20 \pm 6.63$ & $46.24 \pm 34.36$ & $<0.0001$
\end{tabular}

Values are expressed as mean \pm SD or number (\%). BMI-body mass index; n-number; CSA-Chronic stable angina. 
W. Alauddin et al. A Study of Cardiac Autonomic Functions in Patients with Chronic Stable Angina Undergoing Percutaneous Coronary Revascularization

Table 3. Comparison of frequency domain parameters in chronic stable angina patients pre and post Percutaneous Coronary Intervention (PCI).

\begin{tabular}{lllc}
\hline Parameters & $\begin{array}{l}\text { Pre-PCI } \\
(\mathbf{n}=30) \\
\text { Mean } \pm \text { SD }\end{array}$ & $\begin{array}{l}\text { Post-PCI } \\
(\mathbf{n = 3 0}) \\
\text { Mean } \pm \text { SD }\end{array}$ & p Value \\
\hline LF $\left(\mathrm{ms}^{2}\right)$ & $1193 \pm 302.04$ & $1054.60 \pm 208$ & $<0.001$ \\
HF $\left(\mathrm{ms}^{2}\right)$ & $466.72 \pm 257.93$ & $991.57 \pm 872.40$ & $<0.0001$ \\
LF/HF & $1.467 \pm 1.639$ & $1.143 \pm 0.852$ & 0.805 \\
Total Power & $2428 \pm 867.07$ & $3548.37 \pm 807.73$ & $<0.0001$
\end{tabular}

$\left(\mathrm{ms}^{2}\right)$

HRV-heart rate variability; LF-low frequency; HF-high frequency; LF/HF-ratio; $\mathrm{ms}^{2}$ - millisecond squared; $p$ value $<0.05$ statistically significant.

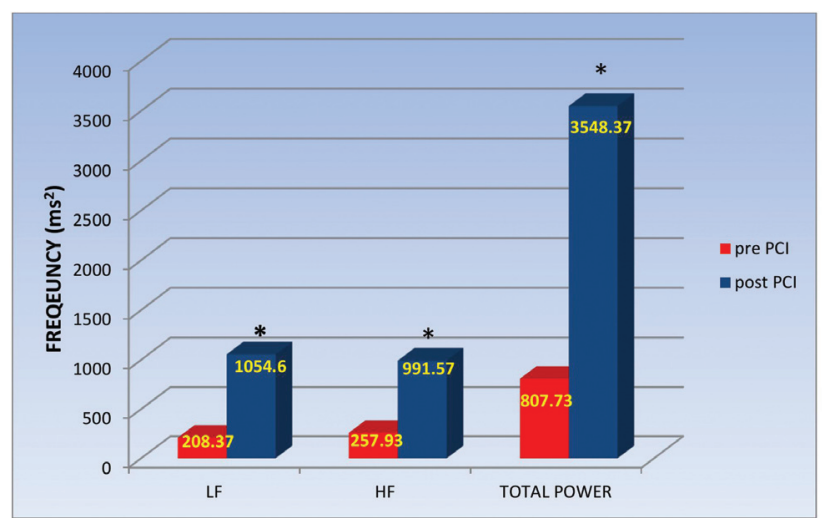

Figure 5. Comparison of frequency domain parameters in chronic stable angina patients pre and post Percutaneous Coronary Intervention (PCI).

LF-low frequency; HF-high frequency; * $p$ value $<0.05$, statistically significant. Post PCI showed significant improvement in LF, HF and Total power as compared to Pre PCI.

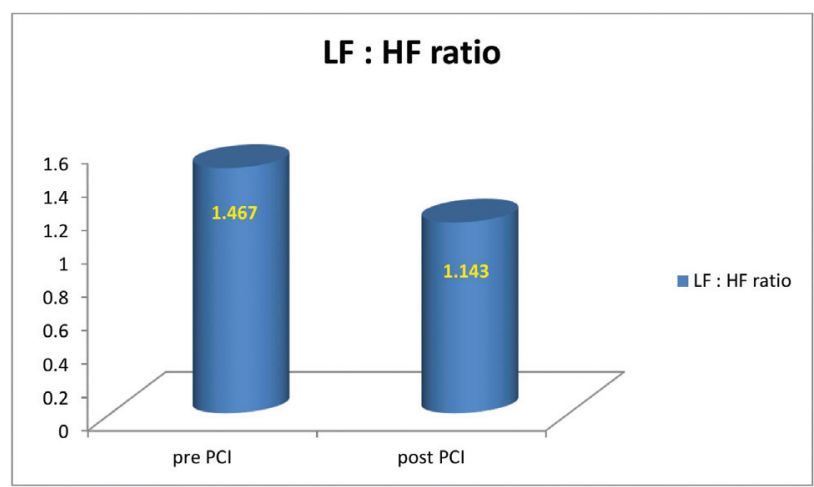

Figure 6. Comparison of LF/HF ratio (low frequency to high frequency ratio) in chronic stable angina patients pre and post. Percutaneous Coronary Intervention (PCI).

Post PCI showed lower LF:HF ratio as compared to Pre PCI

\section{DISCUSSION}

In this study, the pre-PCI time-domain parameters, such as SDNN $(p<0.0001)$, RMSSD $(p<0.0001)$, and pNN50 $(p<0.0001)$ in the CSA patients were significantly lower than the post-PCI values of these parameters.

Frequency-domain parameters such as LF, HF, and TP were also significantly lower in the pre$\mathrm{PCl}$ patients when compared with the post-PCI patients. Though not statistically significant a decrease in LF:HF ratio was observed in the postPCI patients. Reduced SDNN, RMSSD, pNN50, $\mathrm{HF}$, and TP indicate a reduced HRV characterized by an imbalance between the parasympathetic and sympathetic systems and reduced parasympathetic activity. However, a significantly reduced LF implies a reduction in sympathetic activity as well. Thus, our HRV findings reflect autonomic deficit in the pre-PCI patients, with a predominant loss of parasympathetic tone. It is known that HRV exhibits autonomic responses to environmental and external stimuli, which in turn indicate the sympathetic and parasympathetic effects on the heart ${ }^{12}$. HRV analyses provide crucial information about the balance between the sympathetic and parasympathetic influences on the pacemaker of the heart; i.e., the sinoatrial node and its intrinsic rhythm ${ }^{13}$. In a healthy heart, both autonomic nervous system and sinoatrial node are able to respond dynamically to different environmental challenges, thereby resulting in increased HRV. On the other hand, a decreased responsiveness of the autonomic nervous system or the sinoatrial node to a change results in reduced $\mathrm{HRV}^{14}$. Our finding of decrease in HRV parameters in the CSA patients pre-PCI is in accordance with earlier studies and signifies sympathetic predominance and a concomitant parasympathetic deficit in the prePCI CSA patients. Pivatelli et al. ${ }^{15}$ found reduced parasympathetic activity in patients suffering from coronary artery disease with decrease in HF, RMSSD, and NN50; and they stated that these 
parameters could be used as prognostic markers in patients with CSA.

Partly similar to our findings, a study by Aydinlar et al. ${ }^{16}$ also showed that the components of HF, RMMSD, and SDNN were significantly increased whereas LF and LF:HF ratio were significantly reduced after $\mathrm{PCI}$. We observed, though not statistically significant. an increase in LF and a reduction in LF:HF ratio in the post-PCI subjects, According to some reports, the LF spectral component of HRV represents sympathetic nervous activity, whereas others believe it to be the result of both sympathetic and vagal influences ${ }^{11}$. Abrootan et al. ${ }^{17}$ studied the changes in $\mathrm{HRV}$ indices after $\mathrm{PCI}$, and observed an increase in post-PC SDNN. Contrary to our results, Kanadasi et al. ${ }^{18}$ showed that revascularisation of definitive coronary obstruction by $\mathrm{PCI}$ has no beneficial effect on vagal regulation of the heart rate. The possible explanation for a state of sympathetic predominance with reduced parasympathetic component in pre-PCI CSA patients and its reversal following revascularisation by $\mathrm{PCl}$ could be the activation of several neural responses by occlusion of the coronary vessels. Some of these responses are triggered by the stimulation of mechanoreceptors in coronary circulation. Others are induced by the stimulation of the mechanoreceptors and chemoreceptors in the ventricular wall, and the activation of these ventricular receptors is mainly due to the occlusion of the coronary vessels, and thus, myocardial ischemia ${ }^{16}$. Increase in coronary blood flow as well as mechanical stretch are known to result in the stimulation of the mechanoreceptors situated in the left coronary artery which may induce a reflex decrease in the sympathetic drive ${ }^{16}$. Contrarily, occlusion of the left coronary artery experimentally results in the stimulation of mechanoreceptors and chemoreceptors present in the ventricular wall, and this stimulation increases the activity of the sympathetic efferent axons that extend towards the heart ${ }^{16}$.
Abdelnaby et al. ${ }^{19}$ demonstrated that dysfunction of the segmental part of the left ventricle was involved in the imbalance of the sympathovagal system in patients with CSS and that intervention by PCI improved the HRV and the left ventricular dysfunction. These findings support the hypothesis that if cardiac functioning is altered, it leads to the discharge of afferent sympathetic mechanoreceptors, thus causing dysfunction in the autonomic control of the heart rate. The researchers also found increases in post-PCI SDNN, RMSSD, pNN50, LF, and HF. These findings are similar to the observations of the present study.

In patients with single vessel CCS, apart from the dysfunction of the left ventricle, stress indices of the systolic and diastolic wall determine the imbalance of the sympathovagal system synergistically. When the the left ventricular dysfunction is reversed, the indices of wall stress improve the HRV. Alterations in cardiac functioning and ventricular wall stress mainly lead to the discharge of efferent vagal iand afferent sympathetic innervations, thus modulating the long-term instead of short-term heart rate fluctuations ${ }^{8}$.

Similar to our findings, another study by Sedziwy et al. ${ }^{20}$ on the HRV time-domain parameters in pre$\mathrm{PCI}$ and post-PCI patients, concluded that there were significant improvements in HRV, indicating the restoration of the autonomic balance by successful revascularization.

\section{CONCLUSION}

On the basis of our preliminary results, it may be concluded that autonomic dysfunction is present in patients with CSA pre-PCI, and after revascularization procedures such as $\mathrm{PCI}$ that significantly improves cardiac autonomic functions. These findings signify improvements in both basal cardiac autonomic tone and autonomic reactivity in patients with CSA. 


\section{REFERENCES}

1. Prabhakaran D, Jeemon P, Roy A. Cardiovascular diseases in India. Circulation. 2016;133:1605-20. [CrossRef]

2. Wong N. Epidemiological studies of $\mathrm{CHD}$ and the evolution of preventive cardiology. Nat Rev Cardiol. 2014;11:276-89. [CrossRef]

3. Kones R. Recent advances in the management of chronic stable angina I: Approach to the patient, diagnosis, pathophysiology, risk stratification, and gender disparities. Vasc Health Risk Manag. 2010;6:635-56. [CrossRef]

4. O'Toole L. Angina (chronic stable). BMJ Clin Evid. 2008;2008:0213. PMID: 19445795.

5. Dababneh E, Goldstein S. Chronic ischemic heart disease selection of treatment modality. Treasure Island (FL): StatPearls Publishing; 2020.

6. Ghaffari S, Kazemi B, Aliakbarzadeh P. Abnormal heart rate recovery after exercise predicts coronary artery disease severity. Cardiol J. 2011;18:47-54. PMID: 21305485.

7. Kotecha D, New G, Flather MD, Eccleston D, Pepper J, Krum $\mathrm{H}$. Five-minute heart rate variability can predict obstructive angiographic coronary disease. Heart. 2012;98:395-401. [CrossRef]

8. Feng J, Wang A, Gao C, et al. Altered heart rate variability depend on the characteristics of coronary lesions in stable angina pectoris. Anatol J Cardiol. 2015;15:496501. [CrossRef]

9. Gomes ME, Aengevaeren WR, Lenders JW, Verheugt FW, Smits P, Tack CJ. Improving myocardial perfusion by percutaneous coronary intervention reduces central sympathetic activity in stable angina. Clin Cardiol. 2010;33:E16-21. [CrossRef]

10. Lloyd-Jones D, Adams RJ, Brown TM, et al. Executive summary: heart disease and stroke statistics--2010 update: a report from the American Heart Association. Circulation. 2010;121:948-54. [CrossRef]

11. Evrengul $\mathrm{H}$, Tanriverdi $\mathrm{H}$, Kose $\mathrm{S}$, et al. The relationship between heart rate recovery and heart rate variability in coronary artery disease. Ann Noninvasive Electrocardiol. 2006;11:154-62. [CrossRef]

12. Lombardi F, Stein PK. Origin of heart rate variability and turbulence: an appraisal of autonomic modulation of cardiovascular function. Front Physiol. 2011;2:95. [CrossRef]

13. Freeman JV, Dewey FE, Hadley DM, Myers J, Froelicher VF. Autonomic nervous system interaction with the cardiovascular system during exercise. Prog Cardiovasc Dis. 2006;48:342-62. [CrossRef]

14. McMillan DE. Interpreting heart rate variability sleep/ wake patterns in cardiac patients. J Cardiovasc Nurs. 2002;17:69-81. [CrossRef]

15. Pivatelli FC, Dos Santos MA, Fernandes GB, et al. Sensitivity, specificity and predictive values of linear and nonlinear indices of heart rate variability in stable angina patients. Int Arch Med. 2012;5:31. Available from: https:// www.ncbi.nlm.nih.gov/pmc/articles/PMC3549885/

16. Aydinlar A, Sentürk T, Ozdemir B, Kaderli AA, Aydin O. Effect of percutaneous transluminal coronary angioplasty on QT dispersion and heart rate variability parameters. Cardiovasc J Afr. 2009;20:240-4. Available from: https:// www.ncbi.nlm.nih.gov/pmc/articles/PMC3721372/

17. Abrootan S, Yazdankhah S, Payami B, Alasti M. Changes in heart rate variability parameters after elective percutaneous coronary intervention. J Tehran Heart Cent. 2015;10:80-4. Available from: https://www.ncbi.nlm. nih.gov/pmc/articles/PMC4477091/

18. Kanadasi $M$, Kudaiberdieva G, Birand A. Effect of the final coronary arterial diameter after coronary angioplasty on heart rate variability responses. Ann Noninvasive Electrocardiol. 2002;7:106-13. [CrossRef]

19. Abdelnaby $\mathrm{MH}$. Effect of percutaneous coronary intervention on heart rate variability in coronary artery disease patients. Eur Cardiol. 2018;13:60-1. [CrossRef]

20. Sedziwy E, Olszowska M, Tracz W, Pieniazek P. Heart rate variability in patients treated with percutaneous transluminal coronary angioplasty. Przegl Lek. 2002;59:695-8. PMID: 12632888. 